\title{
Synthesis of indole-containing diheteroarylethenes. New probes for photochromic FRET (pcFRET)
}

\author{
Luciana Giordano $^{1}$, Rudolf J. Vermeij ${ }^{2}$, and Elizabeth A. Jares-Erijman ${ }^{1, *}$ \\ 1. Departamento de Química Orgánica. Facultad de Ciencias Exactas y Naturales. Universidad \\ de Buenos Aires. Ciudad Universitaria Pabellón II Buenos Aires. Argentina. ${ }^{2}$ Department of \\ Molecular Biology, Max Planck Institute for Biophysical Chemistry, 37077 Göttingen, Germany \\ Present address: MESA + Institute for Nanotechnology, Faculty of Science and Technology, \\ University of Twente, PO Box 217, 7500 AE Enschede, The Netherlands.
}

Email: eli@qo.fcen.uba.ar

\section{Dedicated to Professor Rosa M. de Lederkremer}

\begin{abstract}
This paper reports a synthesis of novel diheteroarylethenes functionalized for coupling to biomolecules starting from indole derivatives. The strategy is based on the derivatization at the $\mathrm{N}$-atom in the indole substructure. TBDMS protection proved to be superior over BOC protection schemes, leading to higher yields in the overall synthesis. The suitability of the new derivatives as acceptors for pcFRET was calculated for selected donors.
\end{abstract}

Keywords: Photochromism, FRET, diheteroarylethenes, synthesis, indole derivatives

\section{Introduction}

Photochromism is the result of reversible photoisomerization between two isomers that have distinct absorption spectra. The two isomers differ from one another not only in their absorption spectra but also in other physical and chemical properties. ${ }^{1}$ Among the different photochromic compounds diheteroarylethenes are excellent candidates for optoelectronic devices due to their fatigue resistance and thermally irreversible conversion. ${ }^{2}$

Diheteroarylethenes undergo isomerization from an open to a closed form (scheme 1) upon irradiation with UV light. Visible light converts the closed form back into the original open form. Symmetric indole- or pyrrole containing diheteroarylethenes give rise to thermally unstable closed form isomers. By replacing one indole with a furane, thiophene or benzothiophene group, the asymmetric diheteroarylethene becomes thermally stable in the closed form. A number of methyl indole derivatives have been introduced by Irie and coworkers ${ }^{3}$ and the resulting 
photochromic compounds display interesting optical properties which makes them suitable as acceptors for energy transfer for a variety of fluorophore donors.

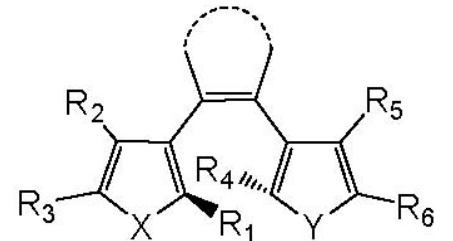

Open Form

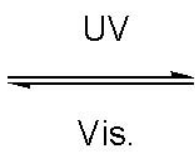

is.

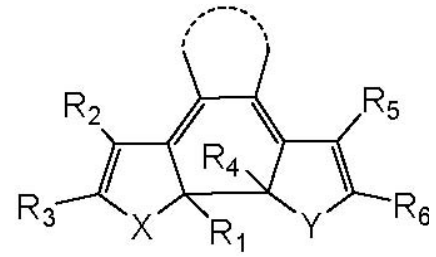

Closed Form

\section{Scheme 1}

FRET (Förster Resonance Energy Transfer) is a physical process by which energy is transferred non-radiatively from an excited molecular fluorophore (donor) to another chromophore (acceptor) via long-range dipole-dipole coupling. The FRET acceptor need not be fluorescent, but must fulfill the requirements of having an absorption spectrum overlapping the emission spectrum of the donor with the respective transition moments in a favorable, i.e. nonorthogonal, relative orientation. We have shown previously that diheteroarylethenes can be used as acceptors for photochromic Förster Resonance Energy Transfer (pcFRET), ${ }^{4} 5$ a technique developed to perform the quantitative determination of FRET in vivo. The photochromic compound is converted from a colorless open form to a FRET-competent acceptor closed form upon irradiation with ultraviolet (UV) light. The open form lacks absorbance in the visible range. Thus, the overlap with the emission of the donor is negligible. The closed form has an absorption band overlapping the emission band of the donor, which can be switched back to the open, nonoverlapping form by exposure to visible light. Multiple “on"/“off” FRET cycles can be generated by alternating exposure to UV and visible light.

Application of photochromic compounds as pcFRET acceptors in biology requires that they contain functional groups that can be used for their conjugation to (bio)molecules. Indole derivatives offer the opportunity for preparing a functionalized substituent on the $\mathrm{N}$ atom. Here we report the synthesis of asymmetric diheteroarylethenes bearing a removable protecting group at this position.

The diheteroarylhexafluorocyclopentenes are usually obtained by a reaction involving nucleophilic attack of a heteroaryllithium on octafluorocyclopentene, followed by elimination of fluoride groups. ${ }^{2}{ }^{6}$ With indole as one of the heteroaryl functionalities, the heteroaryllitium species can be formed by halogen-lithium exchange reaction of the $N$-protected 3-haloindoles. Synthesis of these haloindoles is usually performed by electrophilic substitution. $N$-Protection of the indoles can be carried out before or after the halogenation step. As a result, the requirements of the protecting group are dictated by the lithium-halogen exchange reaction conditions. The synthesis and application of these $N$-protected indoles is well documented: ${ }^{7,} 8$ alkyl, silyl, alkoxymethyl, acyl and other protecting groups have been used. Here we investigated their use for reaction with perfluorocyclopentene. 


\section{Results and Discussion}

The first class of protective group investigated in this synthetic approach was the $t$ butoxycarbonyl group (BOC) (Scheme 2). 3-Iodo-2-methylindole 2 was obtained by iodination of 2-methylindole $\mathbf{1}^{9,10}$ which was followed by protection of the $\mathrm{N}$-position of the indole nucleus to give 3. In order to assess the best reaction conditions, different stoichiometric relationships between $n$-butyllithium and the alkylating reagent $\mathrm{CH}_{3} \mathrm{I}$ were tested (reaction not shown in Scheme). The best yields (65-86\%) were obtained when 2 equivalents of $n$-butyllithium and 1.53 equiv of $\mathrm{CH}_{3} \mathrm{I}$ were used at $-30^{\circ} \mathrm{C}$. Lithiation of the 3 -iodoindole 3 , followed by reaction with excess octafluorocyclopentene led to compound 4 in $42 \%$ yield. However, when a similar substitution reaction of the lithiated indole with compound 7 was attempted, the reaction proceeded sluggishly and only $29 \%$ of the desired product (5) was isolated, recovering $50 \%$ of starting material. When excess $n$-butyllithium was used in the halogen-metal exchange reaction, the desired product was isolated in $20 \%$ yield. In addition, the side product from reaction of unreacted $n$-butyllithium with 7 gave 6 in $48 \%$ (based on 7).

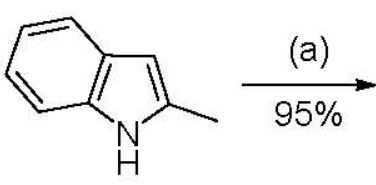

1

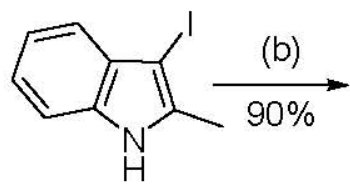

2

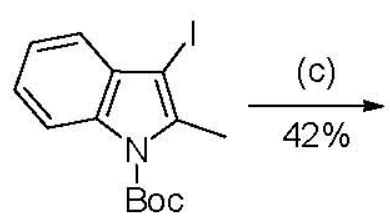

3

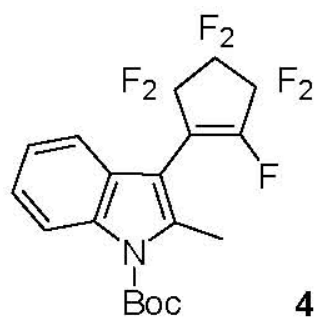

4

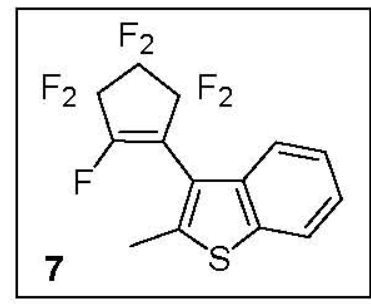

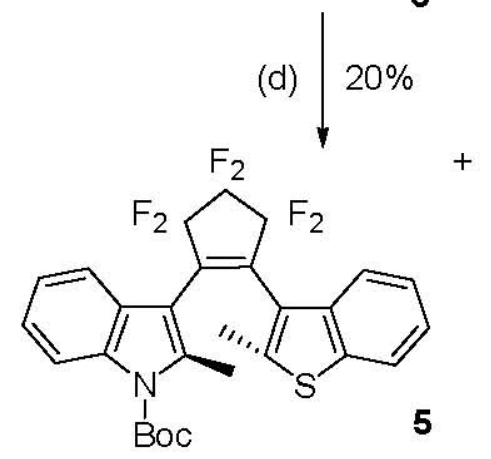

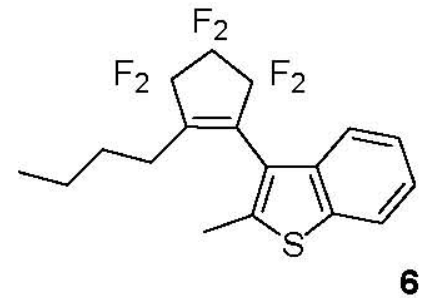

a) $\mathrm{KOH} / \mathrm{I}_{2} / \mathrm{DMF}$ b) $\mathrm{Boc}_{2} \mathrm{O} / \mathrm{TEA} / \mathrm{DMAP} / \mathrm{CH}_{2} \mathrm{Cl}_{2} \mathrm{C}$ ) i) $n$-BuLi $(2.2 \mathrm{eq}) / \mathrm{THF} /-78^{\circ} \mathrm{C}$

ii) $\mathrm{C}_{5} \mathrm{~F}_{8}$ d) i) $n$-BuLi $\left(2.2\right.$ eq) $/ \mathrm{THF} /-78^{\circ} \mathrm{C}$ ii) 7

\section{Scheme 2}

TBDMS was applied in an alternative protection strategy (Scheme 3). 2-Methylindole derivatives $\mathbf{1}$ and $\mathbf{8}$ were deprotonated with $\mathrm{NaH}$ and protected with TBDMSCl yielding $\mathbf{9}$ and 10. Bromination with NBS at $-78^{\circ} \mathrm{C}$ gave $\mathbf{1 1}$ and $\mathbf{1 2} .{ }^{11}$ 


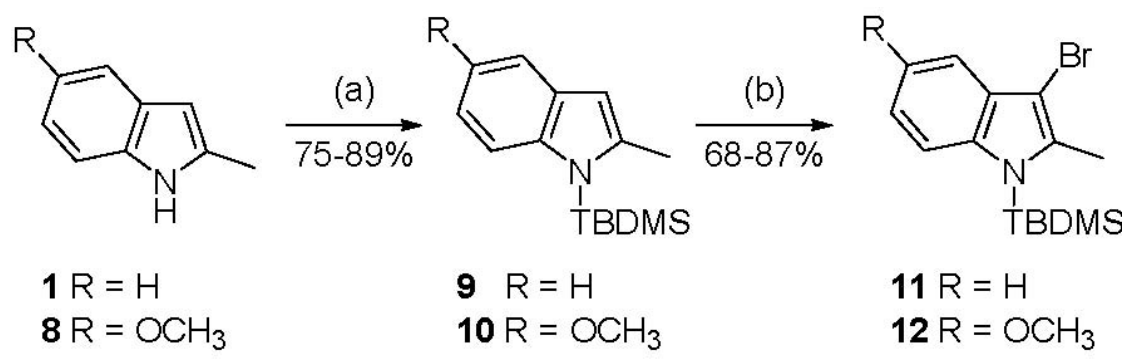

a) i) $\mathrm{NaH} / \mathrm{THF}$ ii) TBDMSCl b) NBS / THF / $-78^{\circ} \mathrm{C}$

\section{Scheme 3}

Lithiation of compounds 11 and 12 with $n$-butyllithium at $-78{ }^{\circ} \mathrm{C}$, followed by reaction with 7 or 16 (11 only) rendered the desired diheteroarylethenes $13-15$ in reasonable yields (Scheme 4). These compounds already contain the photochromic moiety and bear orthogonally protected phenolic $(\mathrm{OH} ; 14$ only) and indolic $(\mathrm{NH})$ functionalities suitable for further derivatizations.

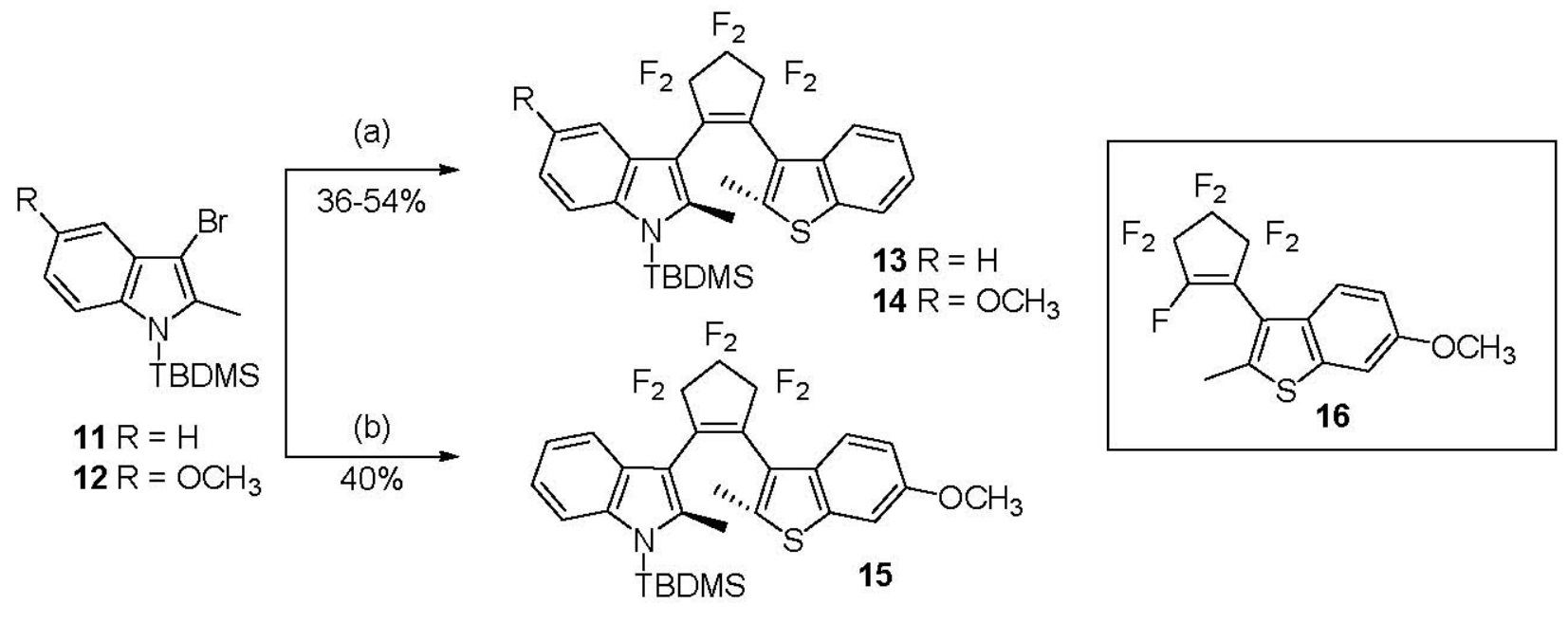

a) i) $n$-BuLi / THF / $-78^{\circ} \mathrm{C}$ ii) 7 b) i) $n$-BuLi / THF / $-78^{\circ} \mathrm{C}$ ii) 16

\section{Scheme 4}

Deprotection of the indole-nitrogen proceeded smoothly with TBAF (Scheme 5). Immediate reaction with $\mathrm{NaH}$ followed by alkylation with ethyl bromoacetate in DMF rendered 18, which by hydrolysis gave the final product 19. ${ }^{12,13}$ Compound 19 contains a carboxylic acid group that can be further activated for conjugation with amine groups. 


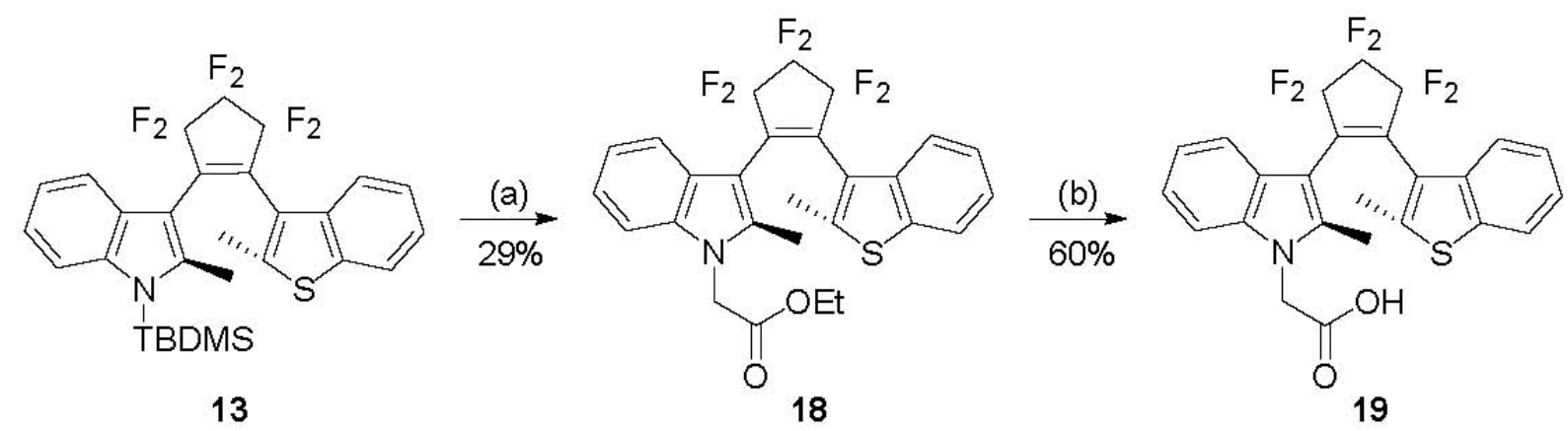

a) i) TBAF (1M) / THF ii) NaH /Ethyl bromoacetate / THF b) NaOH / THF

\section{Scheme 5}

Absorption properties. The absorption spectra of the open- and the closed forms are shown in Figure 1 a and $\mathbf{b}$, respectively.
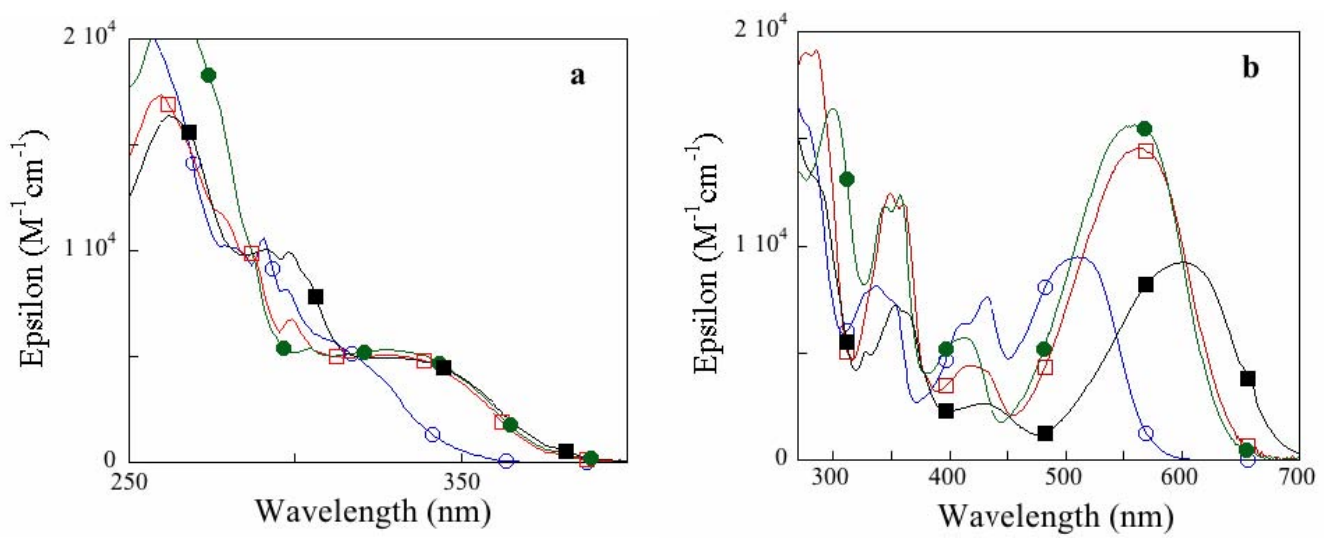

Figure 1. Absorption properties of compounds 5 (blue empty circles), 13 (red empty squares), 14 (black full squares), 15 (green full circles), in the open (a), and in the closed (b) form, respectively.

The optical properties of compounds 5, 13-15 are given in Table I summarizing the absorption maxima corresponding to the open and closed forms, emission maxima of the open form, and the fractional conversion (to the closed form) achieved in the photostationary state by irradiation at the given wavelengths.

The compounds in the open form displayed absorption maxima at 247-270 $\mathrm{nm}$ (figure 1 a). Compounds 5, 13, 14 and 15 had a second maximum at 310-330 nm, and compound 14 presented an additional maximum at $338 \mathrm{~nm}$. The open forms were fluorescent with emission maxima between 425 and $435 \mathrm{~nm}$. 
Table 1. Optical properties of compounds 5, 13-15

\begin{tabular}{|c|c|c|c|c|}
\hline Compound & $\begin{array}{c}\lambda_{\max } \text { Open form } \\
\mathrm{nm} ; \\
\left(\varepsilon, \mathrm{M}^{-1} \mathrm{~cm}^{-1}\right) \\
\end{array}$ & $\begin{array}{c}\text { Photo-conversion } \alpha \\
\left(\lambda_{\text {irr }}, \mathrm{nm}\right)\end{array}$ & $\begin{array}{l}\lambda_{\max } \text { Closed } \\
\text { form, nm; } \\
\left(\varepsilon, \mathrm{M}^{-1} \mathrm{~cm}^{-1}\right) \\
\end{array}$ & $\begin{array}{c}\lambda_{\max } \text { Emission open } \\
\text { form, nm }\end{array}$ \\
\hline 5 & $\begin{array}{l}257(20000) \\
292(7900)\end{array}$ & $\begin{array}{l}0.83(300) \\
0.72(320) \\
0.33(340) \\
0.10(360) \\
0.07(380)\end{array}$ & $\begin{array}{c}268(16600) \\
338(8200) \\
431(7600) \\
511(9500)\end{array}$ & 425 \\
\hline 13 & $\begin{array}{l}261(17200) \\
331(5000)\end{array}$ & $\begin{array}{l}0.40(300) \\
0.49(320) \\
0.38(340) \\
0.17(360) \\
0.13(380) \\
0.69(300)\end{array}$ & $\begin{array}{c}278(19000) \\
300(12000) \\
416(4400) \\
560(14600)\end{array}$ & 435 \\
\hline 14 & $\begin{array}{c}271(14800) \\
300(9800) \\
338(4900)\end{array}$ & $\begin{array}{l}0.72(320) \\
0.64(340) \\
0.38(360) \\
0.23(380)\end{array}$ & $\begin{array}{l}353(7200) \\
428(2600) \\
600(9200)\end{array}$ & 435 \\
\hline 15 & $\begin{array}{l}270(20000) \\
333(5500)\end{array}$ & $\begin{array}{l}0.32(300) \\
0.39(320) \\
0.38(340) \\
0.22(360) \\
0.19(380)\end{array}$ & $\begin{array}{c}300(16400) \\
358(12400) \\
412(5700) \\
558(15600)\end{array}$ & 434 \\
\hline
\end{tabular}

Photochromic properties. All synthesized diarylethenes underwent reversible photochromic reactions in cyclohexane upon alternating exposure to UV $(340 \mathrm{~nm})$ and visible $(546 \mathrm{~nm})$ light. Compounds 5, 13 and 14 displayed two isosbestic points. Compound 5 at 299 and $316 \mathrm{~nm}$; compound 13 at 313 and $321 \mathrm{~nm}$, and compound 14 at 311 and $332 \mathrm{~nm}$. On the other hand, compound 15 had one isosbestic point at $281 \mathrm{~nm}$ and compound 18 lacked an isosbestic point.

Upon irradiation with UV, the color of the solutions went from colorless to red (compounds 5, 15, and 16) or blue (compound 14). The effect of substituent groups on the $N$ atom was evaluated by comparison of the optical properties of the BOC, TBDMS, $\mathrm{CH}_{3},{ }^{2}$ and $\mathrm{CH}_{2} \mathrm{COOR}$ derivatives. The closed form (Figure $1 \mathbf{b}$ ) displayed an absorption maximum at $c a .560 \mathrm{~nm}$ for the TBDMS, $\mathrm{CH}_{3}$ and $\mathrm{CH}_{2} \mathrm{COOR}$ substituents. The maximum was shifted to $511 \mathrm{~nm}$ for the less electron rich $\mathrm{BOC}$ group.

Introduction of a methoxy substituent is known to affect the absorption maxima and extinction coefficient values, depending on its position on the benzothiophene ring of a diarylethene. ${ }^{14}$ A methoxy group on position 6 (compound 15) exerted a negligible change in the 
absorption maximum and displayed a slight increase in $\varepsilon$ compared to 13. On the other hand, the introduction of a methoxy group in the position 5 of the indole moiety (compound 14) introduced a red-shift of $c a .40 \mathrm{~nm}$ compared to compound 13 and a decrease of $\varepsilon$ to $9200 \mathrm{M}^{-1} \mathrm{~cm}^{-1}$.

Indole derivatives as acceptors for pcFRET. The modulation of the emission of a fluorescent donor by pcFRET is based on the difference in the absorption properties of the acceptor in its different photochromic forms. Compounds 5, 13-15 were evaluated as switchable acceptors. Figure 2 displays the absorption spectra corresponding to the open and closed forms of compound $\mathbf{1 5}$ and the emission spectrum of Lucifer yellow (LYC). Compound $\mathbf{1 5}$ displays an effective spectral overlap between its absorption and the emission of the donor (LYC) only in the closed form.

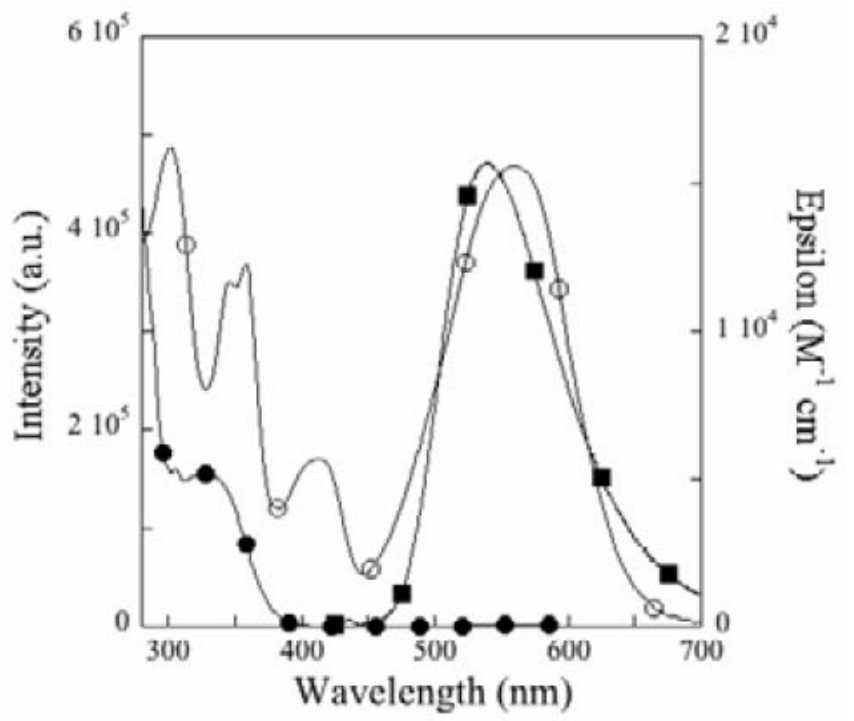

Figure 2. Spectral overlap of the open and closed forms of 15 and LYC. Open (full circles) and closed (empty circles) form extinction coefficients of $\mathbf{1 5}$ correspond to the right axis scale and the emission intensity of LYC (full squares) is given on the left axis.

The overlap integral $J$ and the Förster distance $R_{0}$ were calculated for pairs consisting of the model donor, LYC and the photochromic acceptors, compounds 5, 13-15 in their open and closed forms. Compound 14, with a closed form displaced to the red, was additionally paired with donors sulforhodamine 101 and Nile red. In all cases, the two orders of magnitude difference in the overlap integral between the open and the closed forms demonstrated that the closed form was a competent acceptor, and the open form was not. The derived $R_{0}$ values were between 35-50 $\AA$ for the closed forms and decreased to 10-18 $\AA$ for the open forms.

Table 2. Overlap integral and Förster distances for donor - photochromic acceptor pairs in the open and closed form 


\begin{tabular}{cccccc}
\hline \multirow{2}{*}{ Acceptor } & Donor & $\begin{array}{c}J \text { Open form, } \\
\mathrm{cm}^{6}\end{array}$ & $\begin{array}{c}R_{0} \text { Open form, } \\
\AA\end{array}$ & $\begin{array}{c}J \text { Closed form, } \\
\mathrm{cm}^{6}\end{array}$ & $\begin{array}{c}R_{0} \text { Closed, } \\
\AA\end{array}$ \\
\hline $\mathbf{5}$ & LYC & $3.00 \mathrm{e}-16$ & 15 & $5.12 \mathrm{e}-14$ & 36 \\
$\mathbf{1 3}$ & LYC & $2.88 \mathrm{e}-17$ & 10 & $9.82 \mathrm{e}-14$ & 40 \\
$\mathbf{1 4}$ & LYC & $1.09 \mathrm{e}-16$ & 13 & $6.13 \mathrm{e}-14$ & 36 \\
$\mathbf{1 4}$ & Sulforhodamine & $1.94 \mathrm{e}-16$ & 18 & $1.06 \mathrm{e}-13$ & 51 \\
$\mathbf{1 4}$ & Nile Red & $1.82 \mathrm{e}-16$ & 17 & $9.06 \mathrm{e}-14$ & 48 \\
$\mathbf{1 5}$ & LYC & $1.88 \mathrm{e}-16$ & 14 & $9.63 \mathrm{e}-14$ & 40 \\
\hline
\end{tabular}

\section{Conclusions}

The synthetic scheme using TBDMS as protective group was superior over the use of BOC for the preparation of functionalized, indole derived asymmetric diheteroarylethenes. The substitution on the indole ring at the $\mathrm{N}$-atom had minor effects on the optical properties except for the BOC derivatives. Methoxy groups at position 5 on the indole moiety induced a red-shift of the absorption of the closed form to $600 \mathrm{~nm}$ and a decrease in $\varepsilon$. All photochromic compounds prepared in this work constitute good acceptors that can switch on and off the FRET process in pcFRET.

\section{Experimental Section}

General Procedures. Melting points were determined with a Fisher Jones apparatus and are uncorrected. NMR measurements were carried out on a Bruker $200 \mathrm{MHz}$ AM, $400 \mathrm{MHz}, 500$ MHz AMX, Mercury $300 \mathrm{MHz}$ (Varian) or on a INOVA $500 \mathrm{MHz}$ (Varian) NMR spectrometer. Chemical shifts are in ppm (internal TMS) and coupling constants in Hz. All reactions were monitored by thin-layer chromatography on Merck silica gel plates (60F-254). Column chromatography was performed on silica gel (Merck, 230-400 mesh ASTM). The purities of all final compounds were checked HPLC analysis on a Waters system fitted with a MZSemipreparative Kromasil 100 Sil $5 \mu \mathrm{m}$ silica column (25 cm long, $10 \mathrm{~mm}$ internal diameter). ESI and HRMS were measured on an APEX IV 7 Tesla-Fourier Transform Ion Cyclotron Resonance (FTICR)- Mass spectrometer (Bruker) or on a TSQ 7000 Triple-Stage-QuadrupolInstrument (Finnigan) with Electrospray-Ionisation. Elementary analyses were measured with a Leco CHN2000 analyser with burn unit MICRO U/D (Heraeus). Absorption and fluorescence spectra were measured with a UVIKON 943 Double Beam UV/Vis absorption spectrophotometer and a Perkin Elmer LS50B fluorescence spectrophotometer, respectively. Photoirradiation was carried out using a Superlite SUV-DC-P system incorporating a 200W DC Super-Pressure short arc lamp coupled to a light guide for high UV transmission and an 
electronic timer for exposure time control (Lumatec $\mathrm{GmbH}$, Munich, Germany). Monochromic light was obtained by passing the light a band-pass filter $\left(\Delta \lambda_{1 / 2}=10 \mathrm{~nm}\right)$. The photoconversions were determined with an Ocean Optics fiber optics spectrometer system with a cuvette holder specially modified to allow simultaneous photoconversion and spectral monitoring. Excitation for absorption and fluorescence was with a DT1000A deuterium/tungsten lamp, and detection was with a SD2000 series dual fiber optics spectrometer optimized for detection in the 250-800 $\mathrm{nm}$ spectral region.

FRET Methods. , the critical Förster distance for 50\% FRET efficiency, is defined by $R_{o} R_{o}^{6}=8.785 \cdot 10^{-5} \kappa^{2} \Phi_{D} J n^{-4}$ units, $\mathrm{nm}^{6}$ ) where $\Phi^{L}$ is the quantum yield of the donor in the absence of acceptor, $n$ is the refractive index of the medium, $\kappa^{2}$ is the orientation factor between donor and acceptor (here assumed to be $2 / 3$, the value corresponding to rapid and isotropic reorientation of donor and acceptor during the excited state), and $J$ is the spectral overlap integral between donor and acceptor, given by $J=\int F_{\lambda}^{D} \varepsilon_{\lambda}^{A} \lambda^{4} d \lambda$, where $F_{\lambda}$ is the normalized donor fluorescence spectrum and $\varepsilon_{\lambda}$ is the wavelength-dependent molar extinction coefficient $\left(\mathrm{M}^{-1} \mathrm{~cm}^{-}\right.$ $\left.{ }^{1}\right)$ of the acceptor. For an isolated donor-acceptor pair, the FRET efficiency $E$ varies according to $E=\left[1+\left(r_{D A} / R_{o}\right)^{6}\right]^{-1}$.

Materials. 2-methyl- $1 H$-indole (1), 5-methoxy-2-methyl- $1 H$-indole (8), are commercially available and were obtained from Aldrich Chem. Co. Compounds $7^{15}$ and $16^{14}$ were prepared as previously described.

3-Iodo-2-methyl-1H-indole (2). A solution of $\mathrm{I}_{2}(9.7 \mathrm{~g}, 38 \mathrm{mmol})$ in DMF (65 $\left.\mathrm{ml}\right)$ was added dropwise to a solution of $1(5.0 \mathrm{~g}, 38 \mathrm{mmol})$ and $\mathrm{KOH}(5.3 \mathrm{~g}, 95 \mathrm{mmol})$ in DMF $(80 \mathrm{ml})$ at room temperature and stirred for $30 \mathrm{~min}$. The reaction mixture was poured into ice and water $\left(\begin{array}{ll}1 & 1\end{array}\right)$ containing ammonia $(0.5 \%)$ and sodium metabisulphite $(0.1 \%)$. The orange-white precipitate was filtered and washed with cold water. The obtained 3-iodo-2-methyl-1H-indole 2 (9.3 g, $36 \mathrm{mmol}, 95 \%$ ) was used without further purification. M.p: $82{ }^{\circ} \mathrm{C}$ (lit: $\left.{ }^{16} 83-84{ }^{\circ} \mathrm{C}\right) .{ }^{1} \mathrm{H}-\mathrm{NMR}(400$ $\left.\mathrm{MHz} \mathrm{CDCl}_{3}\right): \delta 8.16(1 \mathrm{H}, \mathrm{bs}, \mathrm{NH}), 7.35(1 \mathrm{H}, \mathrm{m}), 7.25(1 \mathrm{H}, \mathrm{m}), 7.16(2 \mathrm{H}, \mathrm{m}), 2.48(3 \mathrm{H}, \mathrm{s})$.

tert-Butyl 3-iodo-2-methyl-1H-indole-1-carboxylate (3). Compound 2 (1.57 g, $6.1 \mathrm{mmol})$ was dissolved in dichloromethane $(150 \mathrm{ml})$ and treated with di-tert-butyldicarbonate $(1.57 \mathrm{~g}$, $7.2 \mathrm{mmol})$, triethylamine $(2.7 \mathrm{ml}, 19 \mathrm{mmol})$, DMAP $(80 \mathrm{mg}, 0.66 \mathrm{mmol})$ and the reaction mixture was stirred at room temperature for $30 \mathrm{~min}$. The solution was washed twice with sodium metabisulphite $\left(5 \%, 50 \mathrm{ml}\right.$ each time), dried over $\mathrm{Na}_{2} \mathrm{SO}_{4}$ and concentrated under reduced pressure. Chromatography over silica gel (hexane:ethyl acetate = 8:2) gave 3 (1.99 g, $5.6 \mathrm{mmol}$, $90 \%$ ) as a colorless solid. M.p 55-56 ${ }^{\circ} \mathrm{C} .{ }^{1} \mathrm{H}-\mathrm{NMR}\left(400 \mathrm{MHz}, \mathrm{CDCl}_{3}\right): \delta 8.06(1 \mathrm{H}, \mathrm{dd}, J=7.1$ and $2.2 \mathrm{~Hz}), 7.36(1 \mathrm{H}, \mathrm{dd}, J=6.5$ and $2.7 \mathrm{~Hz}), 7.27-7.30(2 \mathrm{H}, \mathrm{m}), 2.72(3 \mathrm{H}, \mathrm{s}), 1.69(9 \mathrm{H}, \mathrm{s}) .{ }^{13} \mathrm{C}-$ NMR (50 MHz, $\left.\mathrm{CDCl}_{3}\right): \delta 149.8,138.2,136.0,131.2,124.5,123.2,120.9,115.4,84.3,71.4$, 28.2 (3C), 17.9. Anal. Calcd. for $\mathrm{C}_{14} \mathrm{H}_{16} \mathrm{INO}_{2}$ (357.19) C 47.08, H 4.52, N 3.92. Found: C 47.02, 
H 4.41, N 3.85. MS (ESI): m/z (\%): $357\left(\mathrm{M}^{+}, 43\right) ; 301$ (100); 257 (80); 130 (15), 57 (97). 3-(2,3,3,4,4,5,5-Heptafluorocyclopent-1-enyl)-1-(t-butoxycarbonyl)-2-methyl-1H-indole (4). A solution of $n-\mathrm{BuLi}$ in hexane $(1.6 \mathrm{M}, 1.0 \mathrm{ml}, 1.6 \mathrm{mmol})$ was added to a stirred solution of 3 $(0.50 \mathrm{~g}, 1.4 \mathrm{mmol})$ in anhydrous THF $(6 \mathrm{ml})$ at $-20^{\circ} \mathrm{C}$ under argon atmosphere. After the addition was complete, the resulting mixture was cooled to $-78{ }^{\circ} \mathrm{C}$ and octafluorocyclopentene $(0.19 \mathrm{ml}, 1.4 \mathrm{mmol})$ was added in a single portion. The mixture was stirred for $1 \mathrm{~h}$ at $-78^{\circ} \mathrm{C}$. The mixture was allowed to warm to room temperature and hydrolyzed with an aqueous $\mathrm{HCl}(1$ $\mathrm{N}, 7 \mathrm{ml})$ solution. The mixture was extracted with ethyl acetate $(4 \times 5 \mathrm{ml})$. The combined organic layers were washed with $\mathrm{H}_{2} \mathrm{O}$ and saturated aqueous $\mathrm{NaCl}$ solution, dried over $\mathrm{Na}_{2} \mathrm{SO}_{4}$ and concentrated under reduced pressure. The crude product was purified by flash column chromatography on silica with hexane and followed by HPLC (silica gel column, hexane) to give 4 as a white solid $(250 \mathrm{mg}, 0.59 \mathrm{mmol}, 42 \%)$. M.p.: $74-75{ }^{\circ} \mathrm{C} .{ }^{1} \mathrm{H}-\mathrm{NMR}\left(500 \mathrm{MHz}, \mathrm{CDCl}_{3}\right)$ : $\delta$ $8.14(1 \mathrm{H}, \mathrm{d}, J=8.3 \mathrm{~Hz}), 7.42(1 \mathrm{H}, \mathrm{d}, J=7.3 \mathrm{~Hz}), 7.27-7.35(2 \mathrm{H}, \mathrm{m}), 2.55(3 \mathrm{H}, \mathrm{s}), 1.71(9 \mathrm{H}, \mathrm{s})$. ${ }^{13} \mathrm{C}-\mathrm{NMR}\left(125 \mathrm{MHz}, \mathrm{CDCl}_{3}\right): \delta 149.9,139.3,135.9,127.0,124.6,123.6,118.7,115.6,85.1$, 28.2 (3C), 15.2. (Resonances of the $C$-atoms of the fluorinated cyclopentene moiety could not be observed due to low intensity and extensive splitting). Anal. Calcd. for $\mathrm{C}_{19} \mathrm{H}_{16} \mathrm{~F}_{7} \mathrm{NO}_{2}$ (423.33): $\mathrm{C}$ 53.91; H 3.81. Found: C 53.70; H 3.66. HRMS: Calcd. 423.1069. Found: 423.1069. MS (ESI) $\mathrm{m} / \mathrm{z}(\%): 423\left(\mathrm{M}^{+}, 22\right), 367$ (48), 323 (66), 301 (24), 257 (22), 57 (100).

\section{3-[3,3,4,4,5,5-Hexafluoro-2-(2-methylbenzo[b]thien-3-yl)-cyclopent-1-enyl]-1-(t-}

butoxycarbonyl)-2-methyl-1H-indole (5). A solution of $n$-BuLi in hexane (1.6 M, $0.77 \mathrm{ml}$, $1.2 \mathrm{mmol})$ was added to a stirred solution of $3(200 \mathrm{mg}, 0.56 \mathrm{mmol})$ in anhydrous THF ( $3 \mathrm{ml})$ at $-78{ }^{\circ} \mathrm{C}$ under nitrogen atmosphere. The resulting mixture was stirred for $30 \mathrm{~min}$ at $-78{ }^{\circ} \mathrm{C}$ and a solution of 7 (200 $\mathrm{mg}, 0.61 \mathrm{mmol})$ in anhydrous THF $(1 \mathrm{ml})$ was added. After the addition was complete, the mixture was allowed to return to room temperature and it was hydrolyzed with an aqueous $\mathrm{HCl}(1 \mathrm{~N}, 5 \mathrm{ml})$ solution. The mixture was extracted with ethyl acetate $(3 \times 5 \mathrm{ml})$. The resulting organic phase was washed with $\mathrm{H}_{2} \mathrm{O}$ and saturated aqueous $\mathrm{NaCl}$ solution, dried over $\mathrm{Na}_{2} \mathrm{SO}_{4}$ and concentrated under reduced pressure. The crude product was purified by flash column chromatography on silica with hexane/ethyl acetate 98:2 to give 5 as a slightly yellow solid (70 mg, $0.13 \mathrm{mmol}, 20 \%)$. M.p.: $71-72{ }^{\circ} \mathrm{C} .{ }^{1} \mathrm{H}-\mathrm{NMR}\left(300 \mathrm{MHz}, \mathrm{CDCl}_{3}\right)(323 \mathrm{~K}): \delta 8.01$ $(1 \mathrm{H}, d, J=7.5 \mathrm{~Hz}), 7.67(1 \mathrm{H}, \mathrm{d}, J=7.0 \mathrm{~Hz}), 7.60(1 \mathrm{H}, \mathrm{d}, J=6.5 \mathrm{~Hz}), 7.50(1 \mathrm{H}, \mathrm{d}, J=7.4 \mathrm{~Hz})$, 7.17-7.27 (4H, m), 2.36-2.31 (6H, bs). Anal. calcd. for $\mathrm{C}_{28} \mathrm{H}_{23} \mathrm{~F}_{6} \mathrm{NO}_{2} \mathrm{~S}$ (551.55): C 60.97, H 4.20, $\mathrm{N}$ 2.54. Found: C 60.74, H 3.96, N 2.62. HRMS Calcd.: 551.1354; found: 551.1354. MS (EI) $\mathrm{m} / \mathrm{z}(\%): 551\left(\mathrm{M}^{+}, 13\right), 495$ (22), 451 (14), 57 (100).

3-(2-Butyl-3,3,4,4,5,5-hexafluorocyclopent-1-enyl)-2-methylbenzo[b]thiophene (6). ${ }^{1} \mathrm{H}-\mathrm{NMR}$ $\left(400 \mathrm{MHz}, \mathrm{CDCl}_{3}\right): \delta 7.78(1 \mathrm{H}, \mathrm{d}, J=7.8 \mathrm{~Hz}), 7.49(1 \mathrm{H}, \mathrm{d}, J=7.9 \mathrm{~Hz}), 7.39(1 \mathrm{H}, \mathrm{m}), 7.34(1 \mathrm{H}$, $\mathrm{m}), 3.81(1 \mathrm{H}, \mathrm{m}), 3.65(1 \mathrm{H}, \mathrm{m}), 2.51(3 \mathrm{H}, \mathrm{s}), 1.46(2 \mathrm{H}, \mathrm{m}), 1.18(2 \mathrm{H}, \mathrm{m}), 0.73(3 \mathrm{H}, \mathrm{t}, J=8 \mathrm{~Hz})$.

1-(tert-Butyldimethylsilanyl)-2-methyl-1H-indole (9). Sodium hydride $(350 \mathrm{mg}, 9.2 \mathrm{mmol}$, mineral oil suspension 50\%) was added in portions to a stirred solution of $\mathbf{1}(1.0 \mathrm{~g}, 7.6 \mathrm{mmol})$ in anhydrous THF $(15 \mathrm{ml})$ and the mixture was stirred for $10 \mathrm{~min}$. tert-Butyl(chloro)dimethylsilane $(1.4 \mathrm{~g}, 9.2 \mathrm{mmol})$ was added and the mixture was stirred for $12 \mathrm{~h}$ at room temperature under 
nitrogen atmosphere. The reaction was quenched with water $(10 \mathrm{ml})$. The mixture was extracted with ethyl acetate $(2 \times 5 \mathrm{ml})$. The organic layer was washed with saturated aqueous $\mathrm{NaCl}$ solution $(10 \mathrm{ml})$, dried over $\mathrm{Na}_{2} \mathrm{SO}_{4}$, filtered and concentrated under reduced pressure. The residue was purified by flash column chromatography on silica (cyclohexane) to give $\mathbf{9}$ as a colorless oil (1.67 g, $6.8 \mathrm{mmol}, 89 \%) .{ }^{1} \mathrm{H}-\mathrm{NMR}\left(200 \mathrm{MHz}, \mathrm{CDCl}_{3}\right): \delta$ 7.46-7.53 (2H, m), 7.03-7.08 (2H, m), $6.34(1 \mathrm{H}, \mathrm{s}), 2.49(3 \mathrm{H}, \mathrm{s}), 0.97(9 \mathrm{H}, \mathrm{s}), 0.67(6 \mathrm{H}, \mathrm{s}) .{ }^{13} \mathrm{C}-\mathrm{NMR}\left(50 \mathrm{MHz}, \mathrm{CDCl}_{3}\right): \delta 142.7,142.0$, $131.3,120.3,119.6,119.1,114.1,106.1,26.8$ (3C), 20.6, 17.5, -0.5 (2C).

\section{3-Bromo-1-(tert-butyldimethylsilanyl)-2-methyl-1H-indole $\quad$ (11). $\quad N$-Bromosuccinimide} (145 mg, $0.81 \mathrm{mmol})$ was added to a solution of 9 (200 $\mathrm{mg}, 0.81 \mathrm{mmol})$ in anhydrous THF $(5 \mathrm{ml})$ at $-78^{\circ} \mathrm{C}$. After $2 \mathrm{~h}$, the mixture was allowed to warm up to room temperature. The mixture was evaporated under reduced pressure. The residue was purified by flash column chromatography (silica, cyclohexane) to give 11 as a white solid (180 mg, $0.56 \mathrm{mmol}, 68 \%) .{ }^{1} \mathrm{H}-$ NMR (200 MHz, $\left.\mathrm{CDCl}_{3}\right): \delta$ 7.48-7.52 (2H, m), 7.18-7.14 (2H, m) $2.53(3 \mathrm{H}, \mathrm{s}), 1.00(9 \mathrm{H}, \mathrm{s}), 0.69$ $(6 \mathrm{H}, \mathrm{s}) .{ }^{13} \mathrm{C}-\mathrm{NMR}\left(50 \mathrm{MHz}, \mathrm{CDCl}_{3}\right): \delta 140.9,138.4,130.0,121.6,120.4,118.4,114.3,95.9$, 26.7 (3C), 20.5,15.5, $-0.3(2 \mathrm{C})$.

\section{1-(tert-Butyldimethylsilanyl)-3-[3,3,4,4,5,5-hexafluoro-2-(2-methylbenzo[b]thien-3-yl)-} cyclopent-1-enyl]-2-methyl-1H-indole (13). A solution of $n$-BuLi in hexane $(1.6 \mathrm{M}, 0.53 \mathrm{ml}$, $0.61 \mathrm{mmol})$ was added to a stirred solution of $11(180 \mathrm{mg}, 0.56 \mathrm{mmol})$ in anhydrous THF $(3 \mathrm{ml})$ at $-78^{\circ} \mathrm{C}$ under argon atmosphere. The resulting orange solution was stirred for $30 \mathrm{~min}$ at $-78^{\circ} \mathrm{C}$ and a solution of $7(210 \mathrm{mg}, 0.61 \mathrm{mmol})$ in anhydrous THF $(1 \mathrm{ml})$ was added. After $30 \mathrm{~min}$ at $78{ }^{\circ} \mathrm{C}$, the mixture was allowed to warm to room temperature and it was hydrolyzed with an aqueous $\mathrm{HCl}(1 \mathrm{~N}, 5 \mathrm{ml})$ solution. The mixture was extracted with ethyl acetate $(2 \mathrm{x} 5 \mathrm{ml})$. The combined organic layers were washed with $\mathrm{H}_{2} \mathrm{O}$ and saturated aqueous $\mathrm{NaCl}$ solution, dried over $\mathrm{Na}_{2} \mathrm{SO}_{4}$ and concentrated under reduced pressure. The crude product was purified by flash column chromatography on silica with hexane/ethyl acetate 98:2 to give a slightly yellow solid (125 mg, $0.22 \mathrm{mmol} 40 \%$ ). Purification by HPLC (silica 60, hexane) gave 13 as a white solid (115 mg, 0.2 mmol, 37\%). M.p.: $162-163{ }^{\circ} \mathrm{C} .{ }^{1} \mathrm{H}-\mathrm{NMR}\left(300 \mathrm{MHz}, \mathrm{CDCl}_{3}\right): \delta$ 7.43-7.64 (4H, m), 7.06-7.24 (4H, m) $2.27(3 \mathrm{H}, \mathrm{bs}), 1.98(3 \mathrm{H}, \mathrm{s}), 0.60(9 \mathrm{H}, \mathrm{s}), 0.54(6 \mathrm{H}, \mathrm{s}) .{ }^{13} \mathrm{C}-\mathrm{NMR}(75 \mathrm{MHz}$, $\left.\mathrm{CDCl}_{3}\right): \delta 142.8,142.2,141.8,138.0,129.0,124.3,124.1,122.2,121.7,121.5,120.7,120.6$, $119.1,119.0,118.9,114.2,26.3$ (3C), 20.5, 15.8, 15.1, -0.2 (2C). (Resonances of the $C$-atoms of the fluorinated cyclopentene moiety could not be observed due to low intensity and extensive splitting). Anal. Calcd. for $\mathrm{C}_{29} \mathrm{H}_{29} \mathrm{~F}_{6} \mathrm{NSSi}$ (565.69): C 61.57, H 5.17; found: C 61.51, H 4.95. MS (ESI) m/z (\%): 565 (M+, 68), 509 (22), 73 (100). HRMS. Calcd.: 565.1694. Found: 565.1694.

\section{1-(tert-Butyldimethylsilanyl)-3-[3,3,4,4,5,5-hexafluoro-2-(6-methoxy-2-methyl-} benzo[b]thien-3-yl)-cyclopent-1-enyl]-2-methyl-1H-indole (15). A solution of $n$-BuLi in hexane (1.6 M, $0.77 \mathrm{ml}, 0.88 \mathrm{mmol})$ was added to a stirred solution of 11 (260 $\mathrm{mg}, 0.80 \mathrm{mmol})$ in anhydrous THF $(3 \mathrm{ml})$ at $-30^{\circ} \mathrm{C}$ under argon atmosphere. The resulting mixture was stirred for $30 \mathrm{~min}$ at $-30{ }^{\circ} \mathrm{C}$ and the mixture was cooled at $-78^{\circ} \mathrm{C}$. A solution of 16 (300 $\left.\mathrm{mg}, 0.80 \mathrm{mmol}\right)$ in anhydrous THF $(1 \mathrm{ml})$ was added. After $30 \mathrm{~min}$ at $-78^{\circ} \mathrm{C}$, the mixture was allowed to warm to room temperature and it was hydrolyzed with an aqueous $\mathrm{HCl}(1 \mathrm{~N}, 5 \mathrm{ml})$ solution. The mixture 
was extracted with ethyl acetate $(2 \times 5 \mathrm{ml})$. The combined organic layers were washed with $\mathrm{H}_{2} \mathrm{O}$ and saturated aqueous $\mathrm{NaCl}$ solution, dried over $\mathrm{Na}_{2} \mathrm{SO}_{4}$ and concentrated under reduced pressure. The crude product was purified by flash column chromatography on silica with hexane/ethyl acetate $98: 2$ to give a white solid (180 $\mathrm{mg}, 0.30 \mathrm{mmol}, 38 \%$ ). Purification by HPLC (silica 60, hexane) gave 15 as a white solid (170 mg, 0.29 mmol, 36 \%). M.p.: 152$153{ }^{\circ} \mathrm{C} .{ }^{1} \mathrm{H}-\mathrm{NMR}\left(300 \mathrm{MHz}, \mathrm{CDCl}_{3}\right): \delta 7.61(1 \mathrm{H}, \mathrm{d}, \mathrm{J}=8.1 \mathrm{~Hz}), 7.44(1 \mathrm{H}, \mathrm{d}, \mathrm{J}=8.3 \mathrm{~Hz}), 7.06-$ $7.13(4 \mathrm{H}, \mathrm{m}), 6.81(1 \mathrm{H}, \mathrm{bs}), 3.80(3 \mathrm{H}, \mathrm{s}), 2.19(3 \mathrm{H}, \mathrm{bs}), 1.97(3 \mathrm{H}, \mathrm{s}), 0.63(9 \mathrm{H}, \mathrm{s}), 0.55(6 \mathrm{H}, \mathrm{s})$. ${ }^{13} \mathrm{C}-\mathrm{NMR}\left(75 \mathrm{MHz}, \mathrm{CDCl}_{3}\right): \delta 157.1,142.8,141.8,139.4,132.1,129.0,122.9,121.5,120.8$, $119.1,119.0,118.9,114.2,114.0,105.7,104.6,55.5,26.4$ (3C), 20.5, 15.8, 15.0, -0.1 (2C). (Resonances of the $C$-atoms of the fluorinated cyclopentene moiety could not be observed due to low intensity and extensive splitting). Anal calcd for $\mathrm{C}_{30} \mathrm{H}_{31} \mathrm{~F}_{6} \mathrm{NOSSi}$ (595.71): C 60.49, H 5.25. Found: C 60.64, H 5.00. MS (EI) m/z (\%): 565 (M+., 100), 539 (25), 538 (26), 73 (76). HRMS. Calcd: 595.1800. Found: 595.1800.

1-(tert-Butyldimethylsilanyl)-2-methyl-5-methoxy-1H-indole (10). Sodium hydride (130 mg, $3.7 \mathrm{mmol}$, mineral oil suspension 50\%) was added in portions to a stirred solution of $8(0.50 \mathrm{~g}$, $3.1 \mathrm{mmol})$ in anhydrous THF $(10 \mathrm{ml})$ and the mixture was stirred for $10 \mathrm{~min}$. tertButyl(chloro)dimethylsilane $(0.56 \mathrm{~g}, 3.7 \mathrm{mmol})$ was added and the mixture was stirred for $12 \mathrm{~h}$ at room temperature under nitrogen atmosphere. The reaction was quenched with water $(10 \mathrm{ml})$. The mixture was extracted with ethyl acetate $(2 \times 5 \mathrm{ml})$. The combined organic layers were washed with saturated aqueous $\mathrm{NaCl}(10 \mathrm{ml})$ solution, dried over $\mathrm{Na}_{2} \mathrm{SO}_{4}$, filtered and concentrated under pressure. The residue was purified by flash column chromatography on silica (cyclohexane) to give 10 as colorless oil $(635 \mathrm{mg}, 2.3 \mathrm{mmol}, 74 \%) .{ }^{1} \mathrm{H}-\mathrm{NMR}(200 \mathrm{MHz}$, $\left.\mathrm{CDCl}_{3}\right): \delta 7.37(1 \mathrm{H}, \mathrm{d}, \mathrm{J}=9 \mathrm{~Hz}), 6.95(1 \mathrm{H}, \mathrm{d}, \mathrm{J}=2.4 \mathrm{~Hz}), 6.70(1 \mathrm{H}, \mathrm{dd}, \mathrm{J}=9$ and $2.4 \mathrm{~Hz}) 6.26$ $(1 \mathrm{H}, \mathrm{s}), 3.83(3 \mathrm{H}, \mathrm{s}), 2.46(3 \mathrm{H}, \mathrm{s}), 0.95(9 \mathrm{H}, \mathrm{s}), 0.64(6 \mathrm{H}, \mathrm{s})$.

3-Bromo-1-(tert-butyldimethylsilanyl)-2-methyl-5-methoxy-1H-indole (12). $N$-Bromosuccinimide (400 mg, $2.3 \mathrm{mmol})$ was added to a solution of $10(635 \mathrm{mg}, 2.3 \mathrm{mmol})$ in anhydrous THF $(10 \mathrm{ml})$ at $-78^{\circ} \mathrm{C}$. After $2 \mathrm{~h}$, the mixture was allowed to warm up to room temperature. The mixture was concentrated under reduced pressure. The crude residue was purified by flash column chromatography (silica, cyclohexane) to give 12 as a white solid (710 mg, $2.0 \mathrm{mmol}$, 87\%). ${ }^{1} \mathrm{H}-\mathrm{NMR}\left(200 \mathrm{MHz}, \mathrm{CDCl}_{3}\right): \delta 7.36(1 \mathrm{H}, \mathrm{d}, J=9.0 \mathrm{~Hz}), 6.91(1 \mathrm{H}, \mathrm{d}, J=2.4 \mathrm{~Hz}), 6.76$ $(1 \mathrm{H}, \mathrm{dd}, J=9.0$ and $2.4 \mathrm{~Hz}), 3.88(3 \mathrm{H}, \mathrm{s}), 2.49(3 \mathrm{H}, \mathrm{s}), 0.97(9 \mathrm{H}, \mathrm{s}), 0.65(6 \mathrm{H}, \mathrm{s}){ }^{13} \mathrm{C}-\mathrm{NMR}(50$ $\left.\mathrm{MHz}, \mathrm{CDCl}_{3}\right): \delta 154.6,139.1,135.6,130.6,115.1,111.4,100.1,95.5,55.7,26.7$ (3C), 20.4, $15.5,-0.4(2 \mathrm{C})$.

\section{1-(tert-Butyldimethylsilanyl)-3-[3,3,4,4,5,5-hexafluoro-2-(2-methylbenzo[b]thien-3-yl)-} cyclopent-1-enyl]-2-methyl-5-methoxy-1H-indole (14). A solution of $n$-BuLi in hexane (1.0 M, $0.93 \mathrm{ml}, 0.93 \mathrm{mmol})$ was added to a stirred solution of $12(300 \mathrm{mg}, 0.85 \mathrm{mmol})$ in anhydrous THF $(10 \mathrm{ml})$ at $-30{ }^{\circ} \mathrm{C}$ under argon atmosphere. The resulting orange mixture was stirred for $30 \mathrm{~min}$ at $-30{ }^{\circ} \mathrm{C}$ and the reaction was cooled at $-78^{\circ} \mathrm{C}$. A solution of 7 (290 $\left.\mathrm{mg}, 0.85 \mathrm{mmol}\right)$ in anhydrous THF $(2 \mathrm{ml})$ was added. After $30 \mathrm{~min}$ at $-78{ }^{\circ} \mathrm{C}$, the mixture was allowed to warm up to room temperature and it was hydrolyzed with an aqueous $\mathrm{HCl}(1 \mathrm{~N}, 5 \mathrm{ml})$ solution. The 
mixture was extracted with ethyl acetate $(2 \times 5 \mathrm{ml})$. The combined organic layers were washed with $\mathrm{H}_{2} \mathrm{O}$ and saturated aqueous $\mathrm{NaCl}$ solution, dried over $\mathrm{Na}_{2} \mathrm{SO}_{4}$ and concentrated under reduced pressure. The crude product was purified by flash column chromatography on silica with cyclohexane/ethyl acetate 98:2 to give 14 as a yellow solid (270 mg, 0.45 mmol 53 \%). M.p.: 167-168 ${ }^{\circ} \mathrm{C} .{ }^{1} \mathrm{H}-\mathrm{NMR}\left(500 \mathrm{MHz}, \mathrm{CDCl}_{3}\right): \delta 7.65(1 \mathrm{H}, \mathrm{bs}), 7.22-7.31(4 \mathrm{H}, \mathrm{m}), 7.01(1 \mathrm{H}, \mathrm{bs}) 6.71$ $(1 \mathrm{H}, \mathrm{d}, J=8.5 \mathrm{~Hz}), 3.76(3 \mathrm{H}, \mathrm{s}), 2.24(3 \mathrm{H}, \mathrm{bs}), 1.98(3 \mathrm{H}, \mathrm{bs}), 0.61(9 \mathrm{H}, \mathrm{s}), 0.53(6 \mathrm{H}, \mathrm{s}) .{ }^{13} \mathrm{C}-$ NMR (125 MHz, $\left.\mathrm{CDCl}_{3}\right): \delta 154.6,143.5,142.3,138.2,136.7,129.7,124.4,124.2,122.4,122.3$, $121.8,114.9,111.1,101.1,55.7,26.4$ (3C), 20.5, 16.0, -0.1 (2C). (Resonances of the $C$-atoms of the fluorinated cyclopentene moiety could not be observed due to low intensity and extensive splitting). MS (EI) m/z (\%): $596\left(\mathrm{M}+\mathrm{H}^{+}, 10\right), 480$ (100).

\section{3-[3,3,4,4,5,5-Hexafluoro-2-(2-methylbenzo[b]thien-3-yl)-cyclopent-1-enyl]-2-methyl-1H-} indole (17). A solution of tetrabutylammonium fluoride (TBAF) in THF (1M, $0.11 \mathrm{ml}$, $0.11 \mathrm{mmol})$ was added to a stirred solution of $\mathbf{1 3}(60 \mathrm{mg}, 0.11 \mathrm{mmol})$ in THF $(1 \mathrm{ml})$, under argon atmosphere. After the solution was stirred for $20 \mathrm{~min}$ at room temperature, it was poured into a saturated solution of $\mathrm{Na}_{2} \mathrm{CO}_{3}(2 \mathrm{ml})$ and extracted with $\mathrm{CH}_{2} \mathrm{Cl}_{2}(3 \times 2 \mathrm{ml})$. The organic layers were combined and washed with $\mathrm{H}_{2} \mathrm{O}(2 \mathrm{ml})$, dried over $\mathrm{Na}_{2} \mathrm{SO}_{4}$, and concentrated under reduced pressure. The residue was subjected to flash column chromatography on silica gel (cyclohexane/ethyl acetate 8:2) to give $40 \mathrm{mg}(0.09 \mathrm{mmol}, 84 \%)$ of the desired compound. Compound 17 was used immediately in the next reaction. ${ }^{1} \mathrm{H}-\mathrm{NMR}\left(200 \mathrm{MHz}, \mathrm{CDCl}_{3}\right): \delta 7.97$ (1H, bs), 7.59-7.69 (3H, m), 7.23-7.28 (2H, m), 7.07-7.18 (3H, m), $2.24(3 \mathrm{H}, \mathrm{s}), 1.94(3 \mathrm{H}, \mathrm{s})$.

Ethyl \{3-[3,3,4,4,5,5-hexafluoro-2-(2-methylbenzo[b]thien-3-yl)-cyclopent-1-enyl]-2-methyl1H-indol-1-yl\}acetate (18). $\mathrm{NaH}(2 \mathrm{mg}, 0.06 \mathrm{mmol}$, mineral oil suspension, 50\%) was added to a stirred solution of 17 (20 mg, $0.04 \mathrm{mmol})$ in DMF $(0.5 \mathrm{ml})$ under $\mathrm{N}_{2}$. After stirring for $30 \mathrm{~min}$, the mixture was cooled and one drop of ethyl bromoacetate was added. The resulting red-brown solution was stirred for $2.5 \mathrm{~h}$ and diluted with $5 \mathrm{ml}$ of ethyl acetate. The organic layer was washed with $\mathrm{H}_{2} \mathrm{O}(3 \times 3 \mathrm{ml})$ and saturated $\mathrm{NaCl}$ solution, dried over $\mathrm{N}_{2} \mathrm{SO}_{4}$ and concentrated to give red oil. The oil was purified by flash column chromatography on silica (cyclohexane/ethyl acetate $8: 2)$ to give $18(8 \mathrm{mg}, 0.01 \mathrm{mmol}, 34 \%)$ as a slightly yellow solid. ${ }^{1} \mathrm{H}-\mathrm{NMR}(200 \mathrm{MHz}$, $\left.\mathrm{CDCl}_{3}\right): \delta 7.62-7.69(3 \mathrm{H}, \mathrm{m}), 7.25-7.31(3 \mathrm{H}, \mathrm{m}), 7.10-7.15(2 \mathrm{H}, \mathrm{m}), 4.63(2 \mathrm{H}, \mathrm{s}), 4.06(2 \mathrm{H}, \mathrm{q}, J$ $=7.1 \mathrm{~Hz}), 2.19(3 \mathrm{H}, \mathrm{s}), 1.90(3 \mathrm{H}, \mathrm{s}), 1.09(3 \mathrm{H}, \mathrm{t}, J=7.1 \mathrm{~Hz})$.

\{3-[3,3,4,4,5,5-Hexafluoro-2-(2-methylbenzo[b]thien-3-yl)-cyclopent-1-enyl]-2-methyl-1Hindol-1-yl\}acetic acid (19). Compound 18 was dissolved in THF (1 ml), an aqueous solution of $\mathrm{NaOH}(1 \mathrm{M}, 0.5 \mathrm{ml}, 0.5 \mathrm{mmol})$ was added, and the mixture was stirred under reflux for $1 \mathrm{~h}$. The reaction mixture was cooled to room temperature and diluted with $\mathrm{H}_{2} \mathrm{O}$. After acidification of the solution to $\mathrm{pH} 1$ using concentrated $\mathrm{HCl}$ the suspension was extracted with $\mathrm{CH}_{2} \mathrm{Cl}_{2}(2 \times 2 \mathrm{ml})$ and the organic phases were dried over $\mathrm{Na}_{2} \mathrm{SO}_{4}$ and concentrated under reduced pressure. The product was purified by preparative thin layer chromatography on reverse phase silica (RP18) with ethyl acetate/2-propanol/ $\mathrm{H}_{2} \mathrm{O}$ 4:3:2 as a solvent to give 19 (4 mg, $\left.0.008 \mathrm{mmol}, 60 \%\right)$ as a slightly yellow solid. ${ }^{1} \mathrm{H}-\mathrm{NMR}\left(200 \mathrm{MHz}, \mathrm{CDCl}_{3}\right): \delta 7.62-7.66(3 \mathrm{H}, \mathrm{m}), 7.26(3 \mathrm{H}, \mathrm{m}), 7.13-7.15$ $(2 \mathrm{H}, \mathrm{m}), 4.65(2 \mathrm{H}, \mathrm{s}), 2.18(3 \mathrm{H}, \mathrm{s}), 1.88(3 \mathrm{H}, \mathrm{s})$. 


\section{Acknowledgements}

The authors would like to thank Dr. Leonardo Erijman and Dr. Thomas Jovin for careful reading of the manuscript. E.A.J.-E. is indebted to the Agencia Nacional de Promoción de la Ciencia y Tecnología (ANPCyT), Fundación Antorchas, Consejo Nacional de Investigaciones Científicas y Técnicas (CONICET), Secretaría de Ciencia, Tecnología e Innovación Productiva (SECyT), Germany-Argentine DLR-BMBF-SECyT, and the Universidad de Buenos Aires (UBA) for financial support. E.A.J.-E. is recipient of the grant I/77 897 from the Volkswagen Foundation for collaborative work on pcFRET with Dr. Thomas Jovin (MPIBPC-Goettingen, Germany).

\section{References}

1. Hirshberg, Compt. Rend. 1950, 231, 903.

2. Irie, M. Chem. Rev. 2000, 100, 1685.

3. Yagi, K.; Irie, M. Bull. Chem. Soc. Jpn. 2003, 76, 1625.

4. Giordano, L.; Jovin, T. M.; Irie, M.; Jares-Erijman, E. A. J. Am. Chem. Soc. 2002, 124, 7481.

5. Jares-Erijman, E. A.; Jovin, T. M. Nat. Biotechnol. 2003, 21, 1387.

6. Hanazawa, M.; Sumiya, R.; Horikawa, Y.; Irie, M. J. Chem. Soc., Chem. Commun. 1992, 206.

7. Greene, T. W.; Wuts, P. G. M. Protective Goups in Organic Synthesis. Wiley-Interscience: New York, $3^{\text {rd }}$ Edn, 1999.

8. Dhanak, D.; Reese, C. B. J. Chem. Soc., Perkin Trans. 1 1986, 2181.

9. Witulski, B.; Buschmann, N.; Bergstrasser, U. Tetrahedron 2000, 56, 8473.

10. Bodwell, G. J.; Li, J. Org. Lett. 2002, 4, 127.

11. Amat, M.; Hadida, S.; Sathyanarayana, S.; Bosch, J. J. Org. Chem. 1994, 59, 10.

12. Cross, P. E.; Dickinson, R. P.; Parry, M. J.; Randall, M. J. J. Med. Chem. 1986, 29, 1637.

13. Bell, M. R.; Dambra, T. E.; Kumar, V.; Eissenstat, M. A.; Herrmann, J. L.; Wetzel, J. R.; Rosi, D.; Philion, R. E.; Daum, S. J.; Hlasta, D. J.; Kullnig, R. K.; Ackerman, J. H.; Haubrich, D. R.; Luttinger, D. A.; Baizman, E. R.; Miller, M. S.; Ward, S. J. J. Med. Chem. 1991, 34, 1099.

14. Frigoli, M.; Mehl, G. H. Chem.- Eur. J. 2004, 10, 5243.

15. Nakashima, H.; Irie, M. Polymer J. 1998, 30, 985.

16. Orazi, O.; Corral, R. A.; Bertorello, H. E. J. Org. Chem. 1965, 30, 1101. 